JEL: Q10; Q11; Q13; Q18

Леся Глубіш

Львівський національний аграрний університет

Україна

\title{
ПЕРЕШКОДИ ФОРМУВАННЮ КОНКУРЕНТНИХ ПЕРЕВАГ У СЕКТОРАХ СФЕРИ ПРОДОВОЛЬЧОГО ЗАБЕЗПЕЧЕННЯ УКРАЇНИ
}

Мета. Мета статті - з'ясувати причини, що уповільнюють набуття конкурентних переваг у секторах сфери продовольчого забезпечення Украӥни в сучасних динамічних умовах.

Методологія / методика / підхід. Методологічною основою дослідження став системний підхід до вивчення економічних явищ та процесів, який дав змогу встановити необхідність вибудовування неперервних виробничо-збутових ланцюгів для набуття конкурентних переваг технологічно спорідненими галузями. В основу характеристики тенденції їхнього розвитку на основі інновацій покладено методику Майкла Портера. Дослідження економічної поведінки українського споживача проведено крізь призму теорії поколінь, щзо допомогло обтрунтувати відмінності в ній.

Результати. Зважаючи на особливості функиіонування продуцентів вітчизняної сфери продовольчого забезпечення, виявлено чинники, щзо відповідають системі умов зовнішньо-економічного середовища та сприяють підвищенню рівня конкурентоспроможності ї̈ складників на основі сталого використання природноресурсного потенціалу нації. Дослідження економічної поведінки консументів ринку продовольства на основі групування населення за поколіннями дало змогу отримати скалярні виміри, які можна агрегувати, враховуючи відмінності в цінностях, щуо сформувалися залежно від місия проживання в конкретний період часу.

Оригінальність / наукова новизна. Наукова новизна полягає в адаптації науковометодологічного підходу формування конкурентних переваг за Портером до обмежень розвитку секторів сфери продовольчого забезпечення Украйни на інноваційній основі із урахуванням ціннісних орієнтацій поколінь ї̈ корінного населення.

Практична цінність / значущість. Напрацьований підхід дає змогу дійти обтрунтованих висновків щодо темпів розвитку секторів сфери продовольчого забезпечення України на інноваційній основі та відповідності вектора набуття конкурентних переваг готовності украӥнського суспільства до прогресивних змін.

Ключові слова: конкурентні переваги, модель харчування, економічна поведінка, сфера продовольчого забезпечення, покоління населення.

Lesya Glubish

Lviv National Agrarian University

Ukraine

\author{
BARRIERS TO CREATING OF COMPETITIVE ADVANTAGES \\ IN THE SECTORS OF FOOD PROVISION SPHERE OF UKRAINE
}




\section{Agricultural and Resource Economics: International Scientific E-Journal}

http://are-journal.com

Purpose. The purpose of the article is to find out the reasons which to slow down gaining of the competitive advantages by the participants of food provision sphere of Ukraine in modern dynamic conditions.

Methodology / approach. The methodological basis of the study was a systematic approach to the investigation of the economic phenomena and processes, which allowed revealing the necessity to build continuous technological chains for gaining competitive advantage into related branches. The tendencies characteristics of its development based on innovations the Michael Porter's method is based on. The study of economic behaviour of Ukrainian consumers was provided through the prism of the Strauss-Howe generational theory.

Results. Based on the peculiarities of the functioning of food provision sphere producers, four common mutually reinforcing factors have been identified that not only correspond to the system of conditions of the external economic environment, but also contribute to increasing the competitiveness of its components based on sustainable use of the nation's natural potential. The studying of economic behaviour of food market consumers on the basis of statistical data taking into account of the population generations allowed to obtain scalar measurements that can be aggregated taking into account differences in values that depends on a person's residence place in a particular period of time.

Originality / scientific novelty. The scientific novelty lies in the adaptation of the scientific and methodological approach to the competitive advantages gaining according to Porter, to the limitations of innovative development of the food provision sphere components of Ukraine, taking into account the generations' valuables orientations of its indigenous population.

Practical value / implications. The developed approach allows making reasonable conclusions about the pace of innovative development of the food provision sphere components of Ukraine and the correspondence of the vector of competitive advantages gaining to the readiness of Ukrainian society for progressive changes.

Key words: competitive advantages, food model, economic behaviour, food provision sphere, population's generations.

Постановка проблеми. Стрімкі глобальні перетворення зумовили високий рівень невизначеності для сучасного економічного життя й непередбачуваність змін. Класична модель ринкової економіки, коли основною метою функціонування економічної системи будь-якого рівня була максимізація прибутку, залишилась у минулому. Нині увага наукового світу зосереджена на удосконаленні підходів, які б давали змогу ефективно використовувати національні ресурси, зважаючи на національні обмеження, що вимагає пошуку концепцій розвитку, орієнтованих на вирішення проблеми задоволення потреб нинішніх поколінь без загрози для майбутніх, оскільки є ризик «мутації» «економіки задоволення потреб» в «економіку жадібності» [1]. Тому дедалі частіше звучать заклики відмовитися від споживацької моделі та переорієнтувати ринкову економіку на моральну, для якої характерним $\epsilon$ домінування моральних цінностей, краще за які ринок діяти не в змозі.

Для сфери продовольчого забезпечення України питання переходу на принципи моральної економіки зумовлене тим, що ключовими факторами виробництва в аграрній сфері $є$ земля та вода - унікальні, незамінні та надзвичайно вагомі природні ресурси. Від їхнього якісного складу залежить якість продуктів харчування, а отже, й стан здоров'я теперішніх і майбутніх поколінь. Тому виникає потреба у виявленні та встановленні співвідношення 


\section{Agricultural and Resource Economics: International Scientific E-Journal}

http://are-journal.com

між чинниками, що сприяють і стримують процес досягнення стану системної стабільності продовольчого забезпечення населення України. Завдання полягає у формуванні конкурентоспроможної сфери продовольчого забезпечення, для ефективного функціонування якої кожна іï структурна компонента повинна мати доступ до необхідних ресурсів, інакше зазнає краху ціла система, наслідком чого стане продовольча криза.

Аналіз останніх досліджень і публікацій. Проблемі продовольчого забезпечення населення присвячено чимало праць представників вітчизняної аграрної науки, зокрема: В. П. Вантуха, К. П. Голікової, Л. В. Дейнеко, I. В. Замикули, Б. Й. Пасхавера, О. В. Шубравської та ін. [2-7]. Однак більшість iз них у пошуку шляхів вирішення продовольчої проблеми зосереджують увагу на необхідності збереження унікальних природно-кліматичних умов без чіткого окреслення ऑii вектора [8]. Українські фахівці орієнтовані на дослідження конкурентних переваг окремих галузей [9] або секторів продовольчого комплексу [4; 10], як правило, у контексті експортних орієнтацій, тому можна стверджувати, що в Україні цьому питанню приділяють недостатньо уваги. Водночас останнім часом зустрічаємо поодинокі праці, де зроблено спробу провести критичний аналіз товаропросування продуктів харчування технологічними ланцюгами 3 позицій соціуму, економіки та екології, розцінюючи перспективи розвитку сільських територій [11]. Натомість британські економісти ще у 2001 р. шукали внутрішні та зовнішні джерела набуття конкурентних переваг у галузевому масштабі, характеризуючи еволюцію цього процесу крізь призму «конкурентних епох». У пострадянському просторі активно обговорюють питання про доцільність набуття конкурентних переваг агропромисловим комплексом науковці сусідньої Білорусі, яку Україні слід розцінювати як одного 3 основних конкурентів на світовому ринку продуктів харчування [12].

Отож, перед нашою державою, аби втримати власні позиції на зовнішніх ринках продовольства та гарантувати продовольчу незалежність, постає необхідність у напрацюванні універсального інструментарію, який би заклав методологічну основу набуття національних конкурентних переваг секторами вітчизняної сфери продовольчого забезпечення та визначення чинників, що перешкоджають їхньому розвитку на інноваційній основі.

Мета статті - 3'ясувати причини, що уповільнюють набуття конкурентних переваг у секторах сфери продовольчого забезпечення України в сучасних динамічних умовах.

Виклад основного матеріалу дослідження. Прагнення вітчизняних аграріїв зайняти лідерські позиції на світовому та вітчизняному ринку продовольства для максимізації економічної вигоди загрожує виснаженням природно-ресурсного потенціалу України, а також, зважаючи на ресурсну спорідненість, скороченням обсягів виробництва харчової промисловості або ж посиленням ï імпортної сировинної залежності. Такий розвиток подій матиме наслідком різке підвищення цін на продовольство та відповідно зростання 
частки витрат міських домогосподарств на його придбання, тоді як реакцією сільських буде зростання рівня самозабезпеченості продуктами харчування. Звідси визначальну роль у вирішенні проблеми продовольчого забезпечення відіграватиме набуття національних конкурентних переваг, від яких залежатиме динамічний розвиток секторів сфери продовольчого забезпечення України [13]. При цьому слід брати до уваги обмеження економічного, екологічного та соціального характеру. Зважаючи на те, що продовольчого забезпечення досягають взаємозв'язком його учасників через їхню взаємодію в економічних процесах, пов'язаних із вирощуванням, збиранням, транспортуванням, переробкою, пакуванням, відвантаженням, збутом і споживанням продуктів харчування, то цілком логічно, що їхня інтеграція має бути спрямована на досягнення високих економічних, екологічних і соціальних показників [14], що є трьома стовпами сталого розвитку [15].

Функціонування вітчизняної сфери продовольчого забезпечення з огляду на нерівномірний розподіл ресурсів та загрозливий вплив інтенсифікації виробничих процесів має орієнтуватися на набуття конкурентних переваг за умови сталого використання природно-ресурсного потенціалу української нації, що вимагає збалансування чотирьох загальних взаємопідсилюючих чинників, які відповідають динамізму умов економічного середовища, формуючи так званий Діамант національних конкурентних переваг (рис. 1).

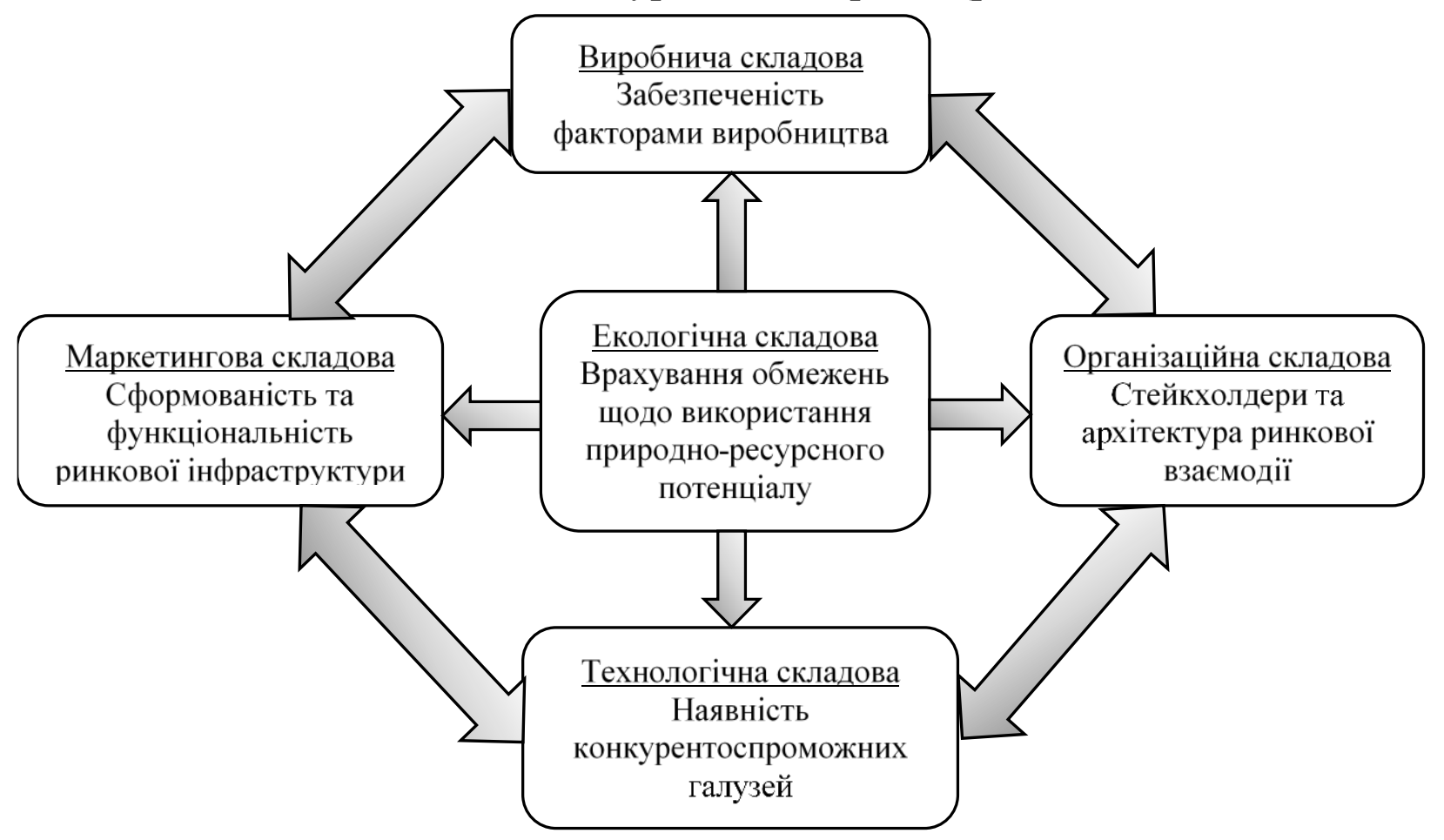

Рис. 1. Діамант національних конкурентних переваг секторів сфери продовольчого забезпечення України

Джерело: побудовано автором на основі [13].

Параметри, що якнайповніше характеризують виробничий, технологічний, маркетинговий та організаційний складники конкурентоспроможності вітчизняної сфери продовольчого забезпечення, корелюють 3 екологічним, 
тобто мають ураховувати обмеження щодо сталого природокористування. Для оцінювання ефективності галузевого управління розвитком і просуванням продовольчої продукції формується система детермінант, що складають поняття «ключові індикатори розвитку сфери продовольчого забезпечення»: озброєність праці, темпи приросту обсягів інвестованого капіталу, залучення кваліфікованого персоналу та економічний результат підприємницької діяльності. За ринкових умов господарювання вони вказують на набуття конкурентних переваг, які є обов'язковою умовою розвитку продуцентів сфери вітчизняного продовольчого забезпечення, що дають їм змогу ефективно конкурувати на внутрішньому та зовнішньому продовольчих ринках [16].

Аналіз конкурентних переваг секторів вітчизняної сфери продовольчого забезпечення свідчить про орієнтацію сільських господарів на максимізацію економічної вигоди в перше десятиліття української державності (табл. 1), на що вказують повільні темпи озброєності праці, попри зростання рентабельності аграрного виробництва, досягнутого завдяки деградованому заниженню заробітної плати в поєднанні 3 недотриманням технологій виробництва сільгосппродукції, зокрема малими обсягами внесення в грунт мінеральних (12,7 кг/га у 1995 р. проти 105,1 кг/га у 1990 р.) та органічних $(1,9$ т/га у 1995 р. проти 6,2 т/га у 1990 р.) добрив, найвищим у світі рівнем розораності сільськогосподарських угідь (56\%), домінуванням монокультури (зернові, соняшник, ріпак, соя), наслідком якого є від'ємний баланс гумусу в грунтах (-0,15 у 1995 р. проти 0,25 у 1990 р.), втрата якого, за підрахунками фахівців ДУ «Інститут охорони грунтів України», у грошовому еквіваленті за період 19902010 рр. становить понад 450 млрд грн (-0,53 станом на 2018 р.) [17].

Несформованість ринку земель сільськогосподарського призначення $\epsilon$ причиною повільних темпів запровадження інновацій в аграрній сфері та заінтересованості іноземного інвестора в репатріації прибутку від інвестованого капіталу. Зняття обмежень щодо виходу на світові продовольчі ринки розвернуло українського інвестора лицем до сільського господарства, що мало наслідком пришвидшення темпів залучення капіталу та зростання рівня оплати праці найманого персоналу, завдяки чому продуктивність праці в сільському господарстві зросла. Обмін досвідом завдяки налагодженню тісної співпраці 3 іноземними партнерами на довгострокову перспективу сприяв розвитку аграрного сектора на інноваційній основі за такими основними напрямами: мінімізація витрат на пально-мастильні матеріали та енергоносії через використання сучасного техніко-технологічного забезпечення; максимізація прибутку через застосування високопродуктивних сортів рослин i систем годівлі, а також високоефективних мінеральних добрив; оптимізація завдяки веденню органічного сільського господарства, позитивним аспектом якого $\epsilon$ замкнутість виробничого циклу, яке $\epsilon$ менш шкідливим для навколишнього природного середовища, оскільки передбачає впровадження аграрних інновацій, що відповідають загальносвітовим трендам. Водночас мають місце істотні диспропорції між наявними інноваціями та потенціалом 
їхнього запровадження [18, с. 53].

Таблиия 1

Аналіз детермінант конкурентних переваг складників сфери продовольчого забезпечення України

\begin{tabular}{|c|c|c|c|c|c|c|c|c|}
\hline \multirow{2}{*}{ Показник } & \multicolumn{7}{|c|}{ Рік } & \multirow{2}{*}{$\begin{array}{l}\text { Зміна, } \\
\%\end{array}$} \\
\hline & 1990 & 1995 & 2000 & 2005 & 2010 & 2015 & 2019 & \\
\hline 1 & 2 & 3 & 4 & 5 & 6 & 7 & 8 & 9 \\
\hline \multicolumn{9}{|c|}{ Сільськогосподарські підприємства } \\
\hline $\begin{array}{l}\text { Наявність енергетичних } \\
\text { потужностей на кінець } \\
\text { року, тис. к. с. }\end{array}$ & 147,1 & н/д & 94,9 & 62,9 & 36,7 & 31,0 & 42,1 & 28,6 \\
\hline $\begin{array}{l}\text { Наявність енергетичних } \\
\text { потужностей на кінець } \\
\text { року на } 100 \text { га посівної } \\
\text { площі, к. с. }\end{array}$ & 484 & н/д & 424 & 341 & 193 & 166 & 1254 & 259,1 \\
\hline $\begin{array}{l}\text { Енергоозброєність } \\
\text { праці, кВт-год }\end{array}$ & 5761 & 3718 & 2054 & 2486 & 1178 & 1080 & 1859 & 32,3 \\
\hline Основні засоби, млн грн & н/д & 14130 & 93392 & 76034 & 73582 & 40217 & 399526 & - \\
\hline Інвестиції, млн грн & 11799 & 1296 & 496 & 5016 & 11311 & 29310 & 58555 & 496,3 \\
\hline $\begin{array}{l}\text { Інвестиції з розрахунку } \\
\text { на } 100 \text { га с.-г. угідь, тис. } \\
\text { грн }\end{array}$ & 28,1 & 3,1 & 1,2 & 12,0 & 27,2 & 70,6 & 141,7 & 504,5 \\
\hline $\begin{array}{l}\text { Продуктивність праці, } \\
\text { тис. грн/особу }\end{array}$ & 25,6 & 14,8 & 12,4 & 33,7 & 63,7 & 223,3 & 334,3 & 1305,8 \\
\hline $\begin{array}{l}\text { Кількість зайнятого } \\
\text { населення, тис. осіб }\end{array}$ & 4344,4 & 4219,1 & 2551 & 4005,5 & 3115,6 & 2870,6 & 3010,4 & 69,3 \\
\hline $\begin{array}{l}\text { Заробітна плата } \\
\text { працівників, грн }\end{array}$ & 232 & 38 & 111 & 437 & 1430 & 3140 & 8738 & 3766,4 \\
\hline $\begin{array}{l}\text { Чистий прибуток від } \\
\text { усієї діяльності, млн грн }\end{array}$ & 11422,8 & 675,6 & $-121,4$ & 3500,7 & 17253,6 & 101912,2 & 90167,0 & 789,4 \\
\hline $\begin{array}{l}\text { Рентабельність усієї } \\
\text { діяльності, \% }\end{array}$ & 98,3 & 55,5 & $-1,0$ & 9,2 & 17,5 & 30,4 & 16,1 & 16,4 \\
\hline \multicolumn{9}{|c|}{ Підприємства харчової промисловості } \\
\hline $\begin{array}{l}\text { Кількість зайнятого } \\
\text { населення, тис. осіб }\end{array}$ & 693 & 576 & 472 & 465 & 387 & 319,5 & 310,5 & 44,8 \\
\hline $\begin{array}{l}\text { Заробітна плата } \\
\text { працівників, грн }\end{array}$ & 213 & 153 & 302 & 894 & 2138 & 4184 & 9986 & 4688,3 \\
\hline Інвестиції, млн грн & 14432 & $\mathrm{H} / \mathrm{д}$ & 2187 & 6418 & 8510 & 13549 & 31889 & 220,9 \\
\hline Основні засоби, млн грн & 81778 & 27025 & 20530 & 44869 & 91985 & 125745 & 207157 & 253,3 \\
\hline $\begin{array}{l}\text { Чистий прибуток, млн } \\
\text { грн }\end{array}$ & $\mathrm{H} / \mathrm{д}$ & $\mathrm{H} /$ д & 5930 & 1487,5 & 2238,8 & 6531,7 & $\mathrm{H} / \mathrm{д}$ & - \\
\hline $\begin{array}{l}\text { Рентабельність опера- } \\
\text { ційної діяльності, \% }\end{array}$ & 26,0 & 24,0 & 3,3 & 3,7 & 4,5 & 6,1 & 5,1 & 19,6 \\
\hline $\begin{array}{l}\text { Рентабельність усієї } \\
\text { діяльності, \% }\end{array}$ & 11 & 22,6 & 1,7 & 1,7 & 0,9 & 2,3 & 1,4 & 12,7 \\
\hline \multicolumn{9}{|c|}{ Заклади готельно-ресторанного господарства } \\
\hline $\begin{array}{l}\text { Кількість зайнятого } \\
\text { населення, тис. осіб }\end{array}$ & & & 100 & 82 & 132 & 85,5 & 96,9 & \\
\hline
\end{tabular}


Agricultural and Resource Economics: International Scientific E-Journal http://are-journal.com

\begin{tabular}{|l|c|c|c|c|c|c|c|c|}
\hline \multicolumn{1}{|c|}{1} & 2 & 3 & 4 & 5 & 6 & 7 & 8 & 9 \\
\hline \multicolumn{1}{|c|}{$\begin{array}{l}\text { Заробітна плата } \\
\text { працівників, грн }\end{array}$} & 184 & 95 & 138 & 510 & 1455 & 2786 & 6730 & 3657,6 \\
\hline $\begin{array}{l}\text { Динаміка місткості } \\
\text { готелів, тис. місць }\end{array}$ & 157,4 & 130,9 & 102,9 & 106,1 & 82 & 132,5 & 166,7 & 105,9 \\
\hline Інвестиції, млн грн & н/д & н/д & 469 & 1508 & 3072 & 1393 & 2832 & - \\
\hline $\begin{array}{l}\text { Основні засоби } \\
\text { суб'єктів, млн грн }\end{array}$ & н/д & н/д & 4934 & 9252 & 31023 & 27276 & 30964 & - \\
\hline $\begin{array}{l}\text { Чистий прибуток, млн } \\
\text { грн }\end{array}$ & н/д & н/д & -200 & 16,4 & $-633,6$ & $-6874,9$ & н/д & - \\
\hline $\begin{array}{l}\text { Рентабельність усієї } \\
\text { діяльності, \% }\end{array}$ & н/д & н/д & $-1,5$ & 0,3 & $-3,8$ & $-17,4$ & н/д & - \\
\hline $\begin{array}{l}\text { Кількість підприємств, } \\
\text { тис. од. }\end{array}$ & 1103 & 1396 & 1308 & 1232 & 1731 & 2478 & 3102 & 281,2 \\
\hline
\end{tabular}

Джерело: побудовано автором за даними статистичного щорічника України за відповідні роки.

Потенціал України у виробництві органічної продукції, іiі успішна сертифікація іноземними структурами та зростаючий попит на неї на внутрішньому й світовому ринках продовольства стимулюють зростання кількості органічних господарств (рис. 2).

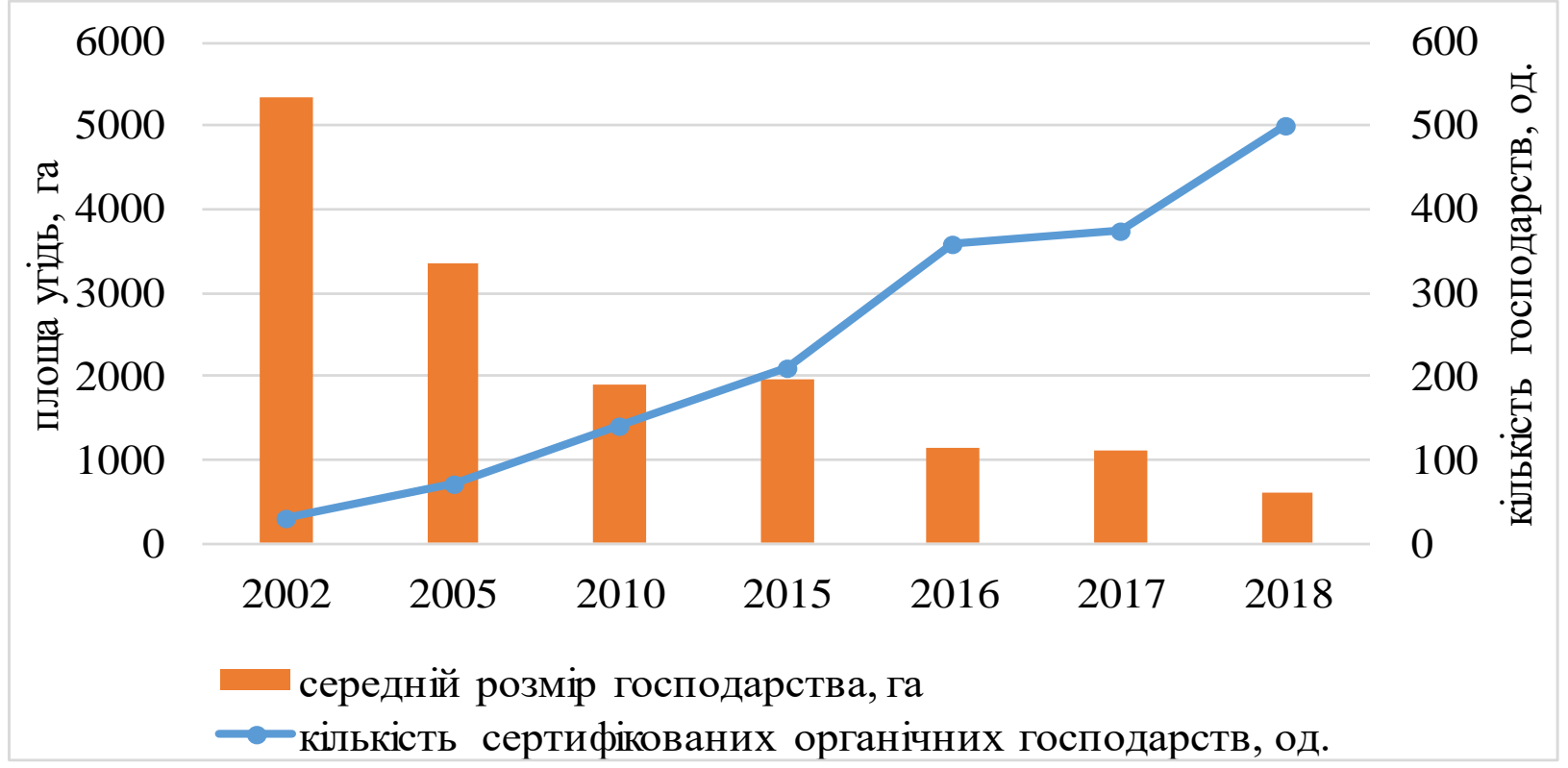

Рис. 2. Динаміка розвитку органічного землеробства в Украӥні

Джерело: побудовано автором на основі даних [19].

Низький рівень економічної ефективності підприємств харчової промисловості, зумовлений експортною орієнтацією аграріїв, продукція яких $\epsilon$ їхньою ресурсною основою, призвів до уповільнення темпів приросту оплати праці найманого персоналу (див. табл. 1). Коливання розміру інвестованого в підприємства харчової промисловості капіталу й темпів приросту вартості основних засобів вказує на його залучення в оновлення асортименту продукції (рис. 3), спроможної відкривати та завойовувати нові ринкові простори. Інноваційність галузей сільського господарства та харчової промисловості 
України є одним із проявів набуття ними конкурентних переваг, що створює елемент гнучкості [20; 21], оскільки гарантує конкурентоспроможність секторів вітчизняної сфери продовольчого забезпечення.

Сфері продовольчого забезпечення, наприклад, Угорщини властиві чотири напрями інновацій: освоєння нових технологій, упровадження у виробництво нових видів продукції, а також ринкові та організаційні інновації [22]. Такої самої стратегії дотримується сусідня Польща, де інновації є одним з атрибутів ефективного продовольчого забезпечення населення [23]. Натомість розвитку харчової промисловості України на інноваційній основі властиві два вектори експансії на вітчизняний та світовий ринки продовольства та мінімізації витрат через автоматизацію виробничих процесів, що пояснює, чому $\epsilon$ істотна неоднорідність як між сегментами ланцюгів товаропросування, так і між ними самими. Цей факт має місце тому, що до уваги не береться готовність суспільства до інновацій того чи іншого характеру, що істотно гальмує їхнє освоєння, тому цілком слушною є теза колективу авторів [20] про необхідність формування інноваційного світогляду суспільства [24]. Однак, на наше переконання, йому має передувати процес визначення поточного рівня.

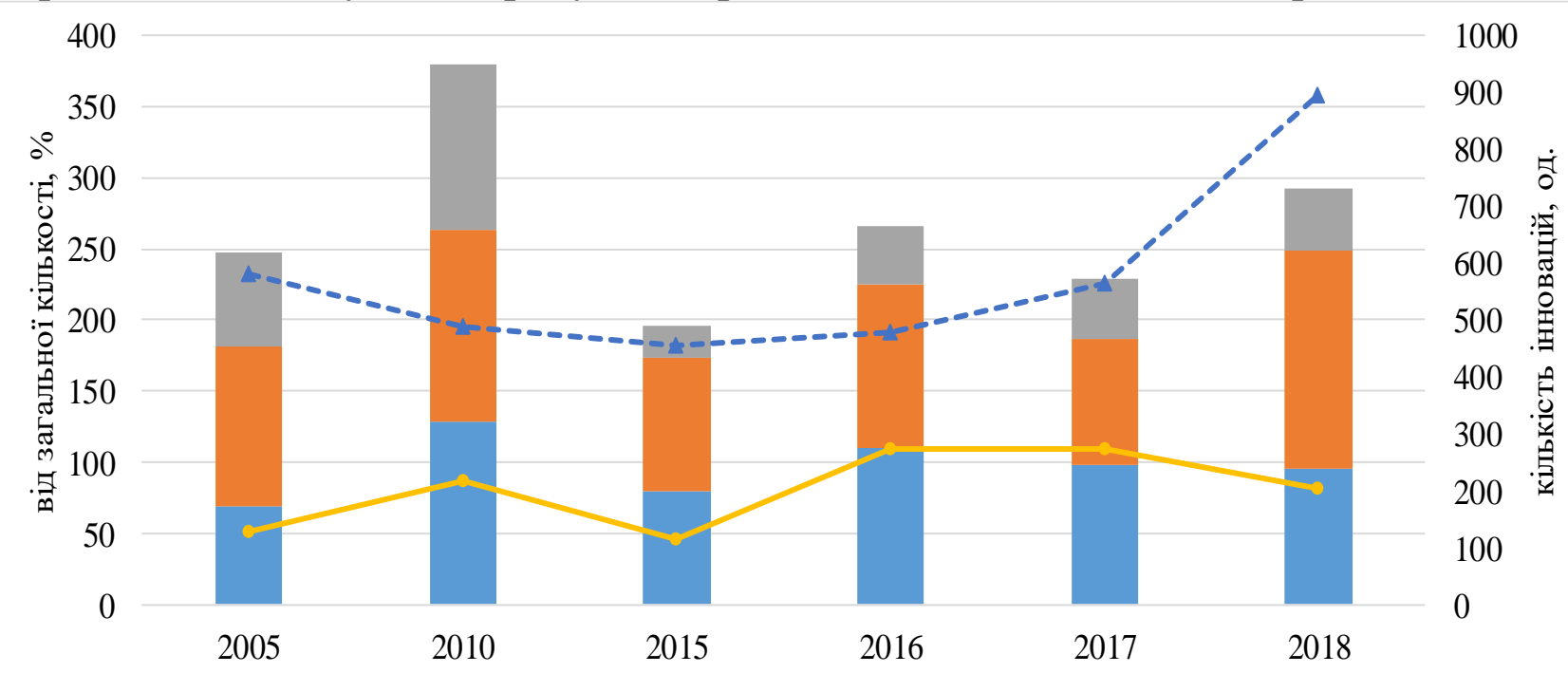

\footnotetext{
впроваджували нові або вдосконалені методи обробки або виробництва продукції, \%

освоювали виробництво інноваційних видів продукції, \%

впроваджували нові технологічні процеси, \%

$\longrightarrow$ нових технологічних процесів, од.

- - виробництво інноваційних видів продукції, найменувань
}

Рис. 3. Інноваційна активність підприсмств харчової промисловості України за ії напрямами

Джерело: побудовано автором за даними статистичного збірника «Наукова та інноваційна діяльність України» за відповідні роки.

Оновлення виробничих потужностей підприємств переробної та харчової промисловості автоматизованими виробничими лініями пояснює зменшення кількості найманого персоналу (табл. 1). Захопленню великого сегмента ринку в короткі проміжки часу сприяє формування вертикально інтегрованих структур, що дає змогу попередити ризик відтворення виробничих процесів 
завдяки налагодженню безперебійного постачання сировини, а також зменшити iі втрати й витрати на транспортування. Вибудувати неперервний виробничозбутовий ланцюг вдалося інтегрованим підприємствам олійної, борошномельно-круп'яної, кондитерської, молокопереробної, лікеро-горілчаної промисловості. Лідерство на ринку рафінованої олії належить «Кернел Холдинг Груп» - 28,1%; компанії «Нібулон» належить 13,7 \% від загального експорту зернових; беззаперечним лідером серед виробників солодощів (37\% ринку) $\epsilon$ кондитерська корпорація «Рошен»; головним постачальником курятини на вітчизняний і світовий ринки є ПрАТ «Миронівський Хлібопродукт», якому належить 87,9 \% їі експорту. Ринок молочної продукції України поділили між собою десять виробників: «Терра Фуд», «Молочний Альянс», «Данон Україна», «Альміра», група компаній «Комо», компанія «Рудь», «Люстдорф», «Мілкіленд Україна», «Вім-Біль-Данн Україна» та «Волошкове поле», частка ринку яких коливається в межах 6-9\%. Найбільшу частку експорту пива займають компанії «САН ІнБев Україна» (32\%), «Оболонь» $(24,5 \%)$ та «Карлсберг Україна» $(29,5 \%)$.

Натомість такими, що перебувають у процесі набуття конкурентних переваг, слід вважати галузі, яким досі притаманна хаотичність формування господарських зв'язків (табл. 2).

Таблиия 2

Результати матричного оцінювання набуття конкурентних переваг галузями сфери продовольчого забезпечення України

\begin{tabular}{|c|c|c|c|}
\hline \multirow{2}{*}{\multicolumn{2}{|c|}{ Показник }} & \multicolumn{2}{|c|}{ Динаміка експансії } \\
\hline & & Низькі темпи (0-36 \%) & Високі темпи (37-59 \%) \\
\hline \multirow[t]{2}{*}{ 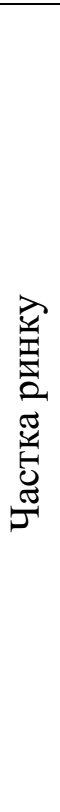 } & 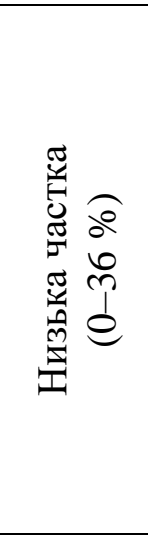 & \begin{tabular}{l}
\multicolumn{1}{c}{ «Новачки» } \\
М'ясне скотарство \\
Овочівництво \\
Ягідництво \\
Рибництво \\
М'ясопереробна промисловість \\
Рибоконсервна промисловість \\
Галузь цукроваріння \\
Садівництво \\
Грибництво
\end{tabular} & $\begin{array}{l}\text { Свинарство } \\
\text { Бджолярство } \\
\text { Виробництво плодоовочевих консервів і } \\
\text { соусів } \\
\text { Виробництво безалкогольних напоїв } \\
\text { Молочне скотарство } \\
\text { Кормовиробництво } \\
\text { Зерновиробництво } \\
\text { Хмелярство } \\
\text { Вирощування олійних культур }\end{array}$ \\
\hline & 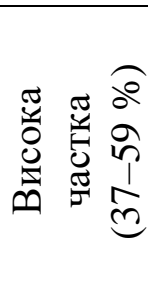 & $\begin{array}{l}\text { «Потенційні лідери» } \\
\text { Птахівництво } \\
\text { Лікеро-горілчана промисловість } \\
\text { Молокопереробна промисловість } \\
\text { Сироварна промисловість }\end{array}$ & $\begin{array}{l}\frac{\text { «Лідери» }}{\text { Кондитерська промисловість }} \\
\text { Пивоварна промисловість } \\
\text { Борошномельно-круп’яна } \\
\text { промисловість } \\
\text { Олійна промисловість }\end{array}$ \\
\hline
\end{tabular}
за 2018 p.

Джерело: побудовано автором за даними статистичного збірника «Україна в цифрах»

Для них характерне інертне збільшення обсягів виробництва продуктів харчування, асортимент і кількість яких, як правило, не відповідає потребі в них, що призводить до перенасичення ними торговельних прилавків, тому 
суб'єкти торгівлі, усвідомлюючи високу ймовірність і масштабність економічних наслідків ризику, пов'язаного з псуванням продовольства в процесі збуту, перекладають його на гаманець покупця.

Водночас збитковою залишається діяльність закладів готельноресторанного господарства України через відсутність злагодженої співпраці 3 торговельними мережами, тому їм властиве формування великої кількості господарських зв'язків із залученням посередницьких структур, що впливає на ціну готової страви в меню, яка визначає доступність харчування населенню України поза домом $з$ поправкою на рівень купівельної спроможності його доходів. Зокрема, чітка взаємозалежність простежується в малих містах i сільській місцевості з властивим їм високим рівнем безробіття (рис. 4).

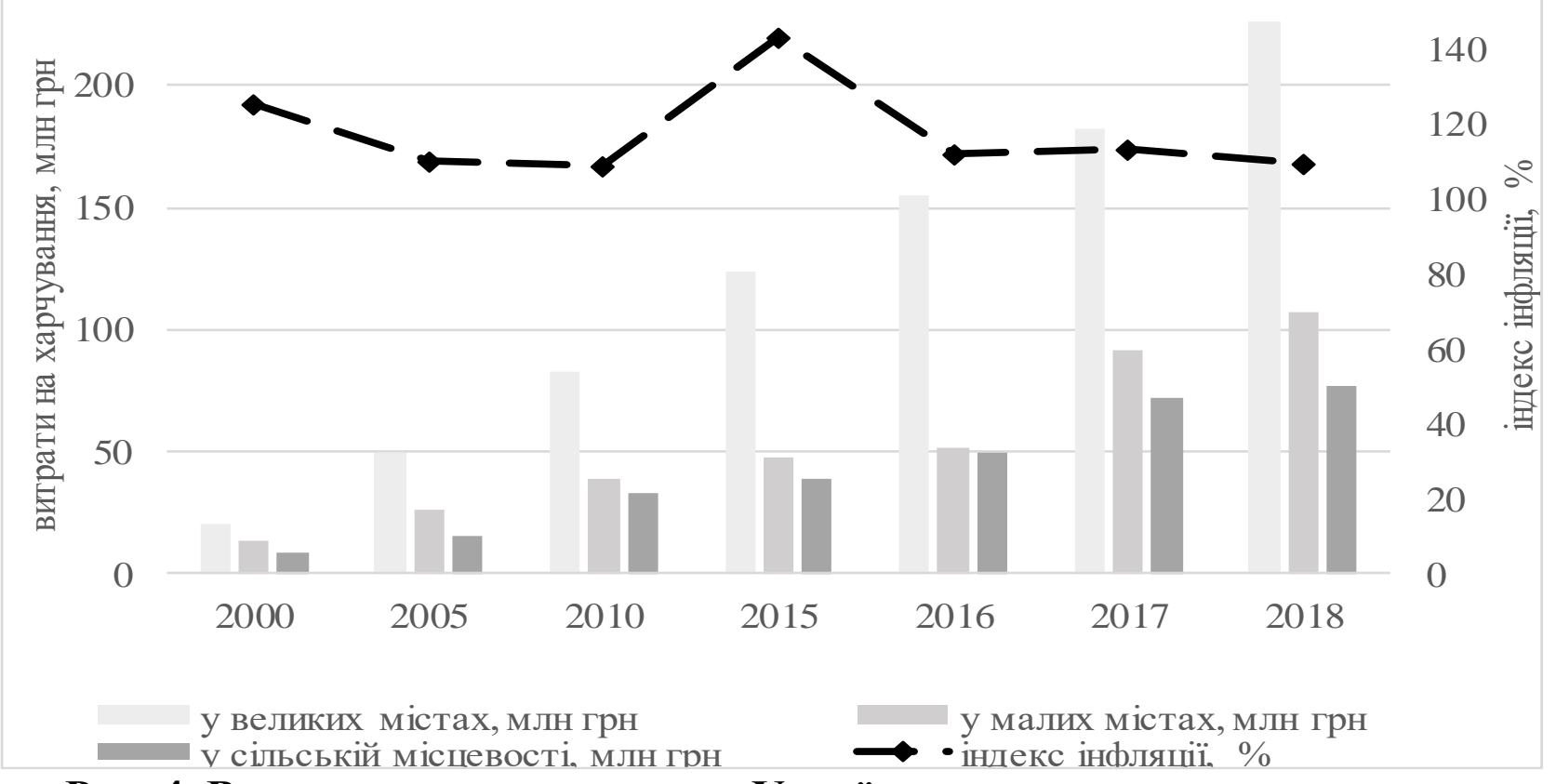

Рис. 4. Витрати домогосподарств України на харчування поза домом залежно від типу населеного пункту

Джерело: побудовано автором за даними статистичного збірника «Витрати і ресурси домогосподарств України» за відповідні роки.

Через відсутність подібної залежності у великих містах може скластися враження, що харчування поза домом $є$ «побічним продуктом» урбанізації. Однак, крім динамізму сучасного життя, темпи розвитку готельно-ресторанного господарства пришвидшуються за умови позитивного приросту туристичних потоків (табл. 3), що закладає основу для розвитку інфраструктури великих міст - культурних і ділових центрів України, досвід яких слід взяти до уваги очільникам маленьких містечок і селищних громад. Соціально-культурний занепад сільських територій $є$ наслідком масової передачі земельних паїв агрохолдингам, які сплачують податки за місцем реєстрації (відповідно до чинного законодавства), що $є$ причиною відсутності джерел наповнення бюджетів значної кількості сільських і селищних громад, унеможливлюючи розвиток їхньої соціальної інфраструктури. У свою чергу, через несформованість останньої та відсутність можливості працевлаштування, 
зумовлену характерною для великотоварного агробізнесу підвищеною фондоозброєністю праці, дедалі менше молоді виявляє бажання залишитися в селі та займатися веденням сільського господарства.

Таблиия 3

\section{Динаміка туристичних потоків в Україні}

\begin{tabular}{|l|c|c|c|c|c|c|c|c|c|}
\hline \multicolumn{1}{|c|}{ Показник } & \multicolumn{7}{|c|}{ Рік } & \multicolumn{2}{|c|}{ Темп } \\
\cline { 2 - 9 } & 1995 & 2000 & 2005 & 2010 & 2015 & 2016 & 2017 & 2018 & зміни \\
\hline $\begin{array}{l}\text { Кількість громадян } \\
\text { України, які виїжджали } \\
\text { за кордон - усього, тис. } \\
\text { осіб }\end{array}$ & 33555 & 13422 & 16453 & 17180 & 24853 & 25500 & 27000 & 27100 & 80,8 \\
\hline $\begin{array}{l}\text { Кількість іноземних } \\
\text { громадян, які відвідали } \\
\text { Україну - усього, тис. } \\
\text { осіб }\end{array}$ & 10365 & 6431 & 17630 & 21203 & 13000 & 15000 & 17000 & 18000 & 173,7 \\
\hline $\begin{array}{l}\text { Кількість туристів, } \\
\text { обслуговуваних } \\
\text { суб'єктами туристичної } \\
\text { діяльності, тис. осіб }\end{array}$ & 3059 & 2014 & 3528 & 3054 & 14635 & 14785 & 16087 & 18706 & 611,5 \\
\hline $\begin{array}{l}\text { Кількість іноземних } \\
\text { туристів, тис. осіб }\end{array}$ & 1068 & 378 & 825 & 917 & 12712 & 12428 & 13333 & 14229 & 1332,3 \\
\hline $\begin{array}{l}\text { Кількість туристів, що } \\
\text { виїжджали за кордон, } \\
\text { тис. осіб }\end{array}$ & 13598 & 285 & 1100 & 1350 & 1600 & 2000 & 2300 & 4000 & 29,4 \\
\hline $\begin{array}{l}\text { Кількість внутрішніх } \\
\text { туристів, тис. осіб }\end{array}$ & 522 & 1351 & 1603 & 787 & 323 & 357 & 454 & 477 & 91,4 \\
\hline
\end{tabular}

Джерело: побудовано автором за даними статистичного збірника «Колективні засоби розміщування в Україні» за відповідні роки.

Надання селянами переваги отриманню пасивного доходу над вирощуванням трудомістких культур пояснює скорочення внеску особистих селянських господарств у виробництво аграрної продукції (рис. 5), що призвело до зростання імпортозалежності України за відповідними культурами. Зокрема, у 2019 р. імпорт картоплі становив 278 тис. т, що удвічі перевищує його обсяг у 1995 р. та на 250 тис. т є більшим, ніж у 2018 році. Подібний стан справ спостерігаємо щодо імпорту фруктів і ягід (приріст імпорту у 2019 р. проти даних 2018 р. становить 174 тис. т) та овоче-баштанних культур (125 тис. т відповідно), площі посіву під якими 3 розвитком орендних відносин у сільському господарстві через домінування монокультури на полях зменшилися за період з 1995 до 2019 pp. на 248 тис. га. Вирішенню соціальних питань сільських територій допоможе поєднання органічного сільського господарства 3 маркуванням продуктів харчування із географічним зазначенням унікальності природних умов і культурних традицій території їхнього походження.

Відокремлення процесів розвитку виробничих, збутових і соціальних систем вказує на те, що суспільство не може розвиватися лише 3 опорою на ринок [25, с. 19]. Виникає потреба в доповненні ринкових вимірників результатами оцінки соціального прогресу, які відображають готовність 
суспільства до змін. 3 огляду на це актуалізуються наукові дослідження щодо виявлення та з'ясування причин виникнення поведінкових аномалій споживача, що трактуються як відхилення від раціональної поведінки [26]. Водночас постає питання, яку економічну поведінку споживача слід вважати раціональною, оскільки мотивація й потреби, що стоять за рішенням про місце харчування та наповнення продовольчого кошика, зазнають значних варіацій залежно від поколінь, кожному 3 яких притаманні свої цінності, що формувалися під впливом умов середовища, в якому вони набували свого життєвого досвіду [27]. Тому соціальне оцінювання продовольчого забезпечення корінного населення України може істотно різнитися від традиційного економічного.

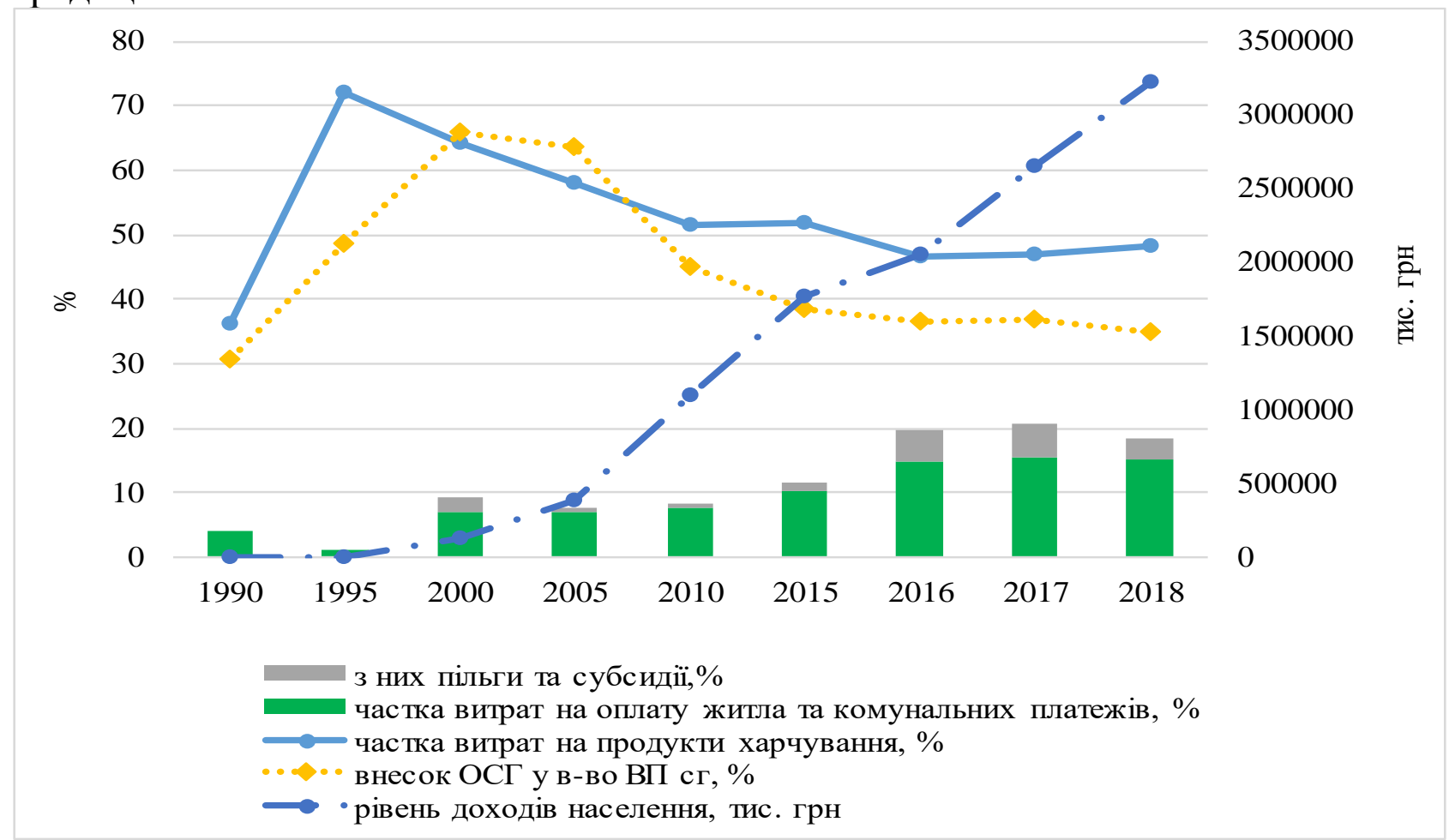

Рис. 5. Вплив урбанізації та рівня доходів населення України на чутливість попиту на продовольство

Джерело: побудовано автором за даними статистичного збірника «Витрати і ресурси домогосподарств України» і статистичного збірника «Сільське господарство України» за відповідні роки.

Як показує практика, модель харчування є віддзеркаленням національної культури, сформованої історичним минулим нації, яка, зазнаючи змін під впливом часу, формує відповідну споживчу поведінку корінного населення країни. Істотний відбиток на культуру харчування наклав досвід, який українська нація отримала у XX столітті, переживши три голодомори. Відтоді велике значення для українців старшого покоління (61 рік і більше) має ситна їжа, тому в їхніх харчових раціонах переважають висококалорійні продукти 3 борошна, що були в ті важкі часи єдиним порятунком від голодної смерті. Загалом особам пенсійного віку властива заощадливість, а через низький рівень доходів - консерватизм щодо домашнього харчування. Середні за віком 


\section{Agricultural and Resource Economics: International Scientific E-Journal}

http://are-journal.com

українці (31-60 років) виховані в традиціях старшого покоління із вкрапленнями гастрономічних смаків, набутих у процесі власного життєвого досвіду, сформованого завдяки можливості вільного пересування світом і доступу до інформаційних ресурсів. Вони прискіпливо ставляться до вибору продуктів харчування, надають перевагу домашній їжі ще й через бажання фінансово підтримати своїх дітей, тому харчуються поза домом лише за нагоди або необхідності. Економічну поведінку цих двох поколінь формувало радянське минуле 3 властивим йому нерівномірним i нераціональним розподілом продовольства, який доволі таки часто набував ознак продовольчого дефіциту, тому їм притаманне створення продовольчих запасів. Тоді як сучасна українська молодь (16-30 років), яка росла у вік інформаційних технологій і звикла до достатку та батьківського піклування, схильна до вибору такої моделі життя, що дає змогу задовольнити іiі прагнення до більшої мобільності 3 відповідним скороченням кількості часу на харчування. Прагнення до урізноманітнення смаків спонукає цю вікову категорію населення регулярно використовувати програми для замовлення їі. Рішення про місце харчування та наповнення продовольчого кошика населення середнього віку та молодого покоління залежить не лише від надмірної диференціації доходів та рівня гастрономічної культури, а й від бажання слідувати моді чи відповідати певному соціальному статусу, супутнім явищем якого є хизування багатством, що є одним із культурних феноменів європейського соціуму [28, с. 28-29].

Споживчий потенціал вітчизняного ринку продуктів харчування результат комбінації обмежень соціального та економічного характеру. Істотні відмінності в структурі доходів різних поколінь населення України формують відповідні варіації в структурі споживчого попиту (табл. 4), який належить характеризувати, враховуючи властиві їм стандартні набори потреб.

Основним деструктивним чинником економічної рівноваги на внутрішньому ринку продуктів харчування $\epsilon$ зростання випереджальними темпами тарифів на енергоносії, що призводить до пропорційного підвищення цін на продовольство та відповідно диспаритетного руйнування купівельної спроможності українського споживача [29]. Для пенсіонерів, крім витрат на продукти харчування та комунальні послуги, до пріоритетних належать витрати на охорону здоров'я, а саме придбання медикаментів, тоді як для осіб середнього віку - витрати, пов'язані із веденням домашнього господарства та освітою, яку вони прагнуть дати своїм нащадкам, а для молоді - на предмети домашнього вжитку й транспортні засоби, що вказує на пріоритет комфорту та мобільності.

Оскільки споживчий попит є основною рушійною силою, що спонукає до ринкової взаємодії усі їі сторони та запускає економічні процеси, пов'язані 3 організацією матеріально-ресурсних потоків, або ж уповільнює їх, то модель «Діамант національних конкурентних переваг» секторів сфери продовольчого забезпечення доцільно доповнити віссю попиту, в результаті чого вона із ромба трансформується в октаедр, «екватором» якого $\epsilon$ виявлення чинників та 
встановлення ступеня їхнього впливу на попит (рис. 6).

Таблиия 4

\section{Варіативність структури сукупних доходів і витрат населення України,} згрупованого за поколіннями, \%

\begin{tabular}{|c|c|c|c|c|c|c|c|c|c|}
\hline \multirow[t]{2}{*}{ Стаття доходів/витрат } & \multicolumn{3}{|c|}{$\begin{array}{c}\text { Особи пенсійного } \\
\text { віку (61 рік і більше) }\end{array}$} & \multicolumn{3}{|c|}{$\begin{array}{l}\text { Особи середнього } \\
\text { віку (31-60 років) }\end{array}$} & \multicolumn{3}{|c|}{$\begin{array}{c}\text { Особи молодого } \\
\text { віку (16-30 років) }\end{array}$} \\
\hline & 2000 & 2010 & 2019 & 2000 & 2010 & 2019 & 2000 & 2010 & 2019 \\
\hline \multicolumn{10}{|c|}{ Структура сукупних ресурсів } \\
\hline Пенсія & 50 & 52 & 62 & 0,4 & 1,1 & 2,3 & 0,4 & 0,6 & 3,1 \\
\hline Оплата праці & 38 & 28 & 15 & 58 & 56 & 59 & 40,7 & 37,6 & 44,1 \\
\hline $\begin{array}{l}\text { Доходи від } \\
\text { підприємницької } \\
\text { діяльності та } \\
\text { самозайнятості } \\
\end{array}$ & 1,2 & 2,1 & 7,3 & 6,4 & 19,7 & 20,3 & 17,4 & 23,6 & 12,6 \\
\hline $\begin{array}{l}\text { Доходи від продажу с.-г. } \\
\text { продукції }\end{array}$ & 8,4 & 10 & 11,7 & 21,7 & 12,4 & 6,1 & 17,3 & 8,9 & 6,9 \\
\hline Доходи від власності & 3,0 & 3,1 & 2,1 & 7,3 & 8,4 & 9,3 & 0,2 & 3,9 & 5,7 \\
\hline Стипендії & 0 & 0 & 0 & 0 & 0 & 0 & 8,4 & 12,4 & 14,3 \\
\hline $\begin{array}{l}\text { Допомоги, пільги, } \\
\text { субсидії }\end{array}$ & 0,2 & 2,7 & 1,2 & 0,7 & 1,2 & 0,9 & 2,1 & 2,7 & 3,4 \\
\hline $\begin{array}{l}\text { Грошова допомога від } \\
\text { родичів }\end{array}$ & 0,8 & 1,9 & 0,7 & 2,1 & 0,9 & 1,1 & 5,9 & 4,1 & 5,5 \\
\hline Аліменти & 0 & 0 & 0 & 0,3 & 0,1 & 0,7 & 1,2 & 1,1 & 2,9 \\
\hline Інші грошові доходи & 0,3 & 0,2 & 0 & 3,1 & 0,2 & 0,3 & 5,4 & 6,1 & 1,5 \\
\hline \multicolumn{10}{|c|}{ Структура сукупних видатків } \\
\hline $\begin{array}{l}\text { Продукти харчування (у } \\
\text { тому числі алкогольні } \\
\text { напої й тютюнові вироби) }\end{array}$ & 74,8 & 72,1 & 68,4 & 71,4 & 58,7 & 54,3 & 73,4 & 59,6 & 56,1 \\
\hline Комунальні послуги & 12,2 & 12,7 & 14,7 & 10,6 & 11,6 & 12,9 & 9,8 & 10,9 & 13,7 \\
\hline Охорона здоров’я & 5,6 & 5,9 & 8,2 & 4,8 & 4,2 & 3,3 & 1,2 & 2,8 & 3,1 \\
\hline $\begin{array}{l}\text { Предмети домашнього } \\
\text { вжитку }\end{array}$ & 2,4 & 3,1 & 3,2 & 3,1 & 5,2 & 4,4 & 2,3 & 6,7 & 7,2 \\
\hline Освіта & 0 & 0 & 0 & 1,6 & 5,9 & 10,4 & 3,4 & 5,2 & 7,4 \\
\hline Відпочинок & 1,1 & 2,1 & 2,5 & 2,4 & 7,4 & 6,1 & 5,9 & 7,6 & 5,4 \\
\hline Транспорт & 2,1 & 2,4 & 1,2 & 3,1 & 3,9 & 5,1 & 2,1 & 5,2 & 4,4 \\
\hline Зв'язок & 1,8 & 1,7 & 1,8 & 3 & 3,1 & 3,5 & 1,9 & 2 & 2,7 \\
\hline
\end{tabular}

Джерело: розраховано автором на основі даних статистичного збірника «Витрати i ресурси домогосподарств України» та демографічного щорічника «Населення України» за відповідні роки.

У такий спосіб формується площина, що уособлює соціально-економічну дійсність, яка визначає доцільність інновацій, розмір інвестицій, під які обмежують чинники, що визначають обсяг і вектор попиту. Модель-октаедр передбачає вибір стратегічних граней використання конкурентних переваг стейкхолдерами вітчизняної сфери продовольчого забезпечення в напрямі, відповідному сукупності чинників, що формують економічну поведінку споживача, ядром якої є його цінності, оскільки визначають набір економічних потреб і характеристики економічних благ, що мають їх задовольнити. 


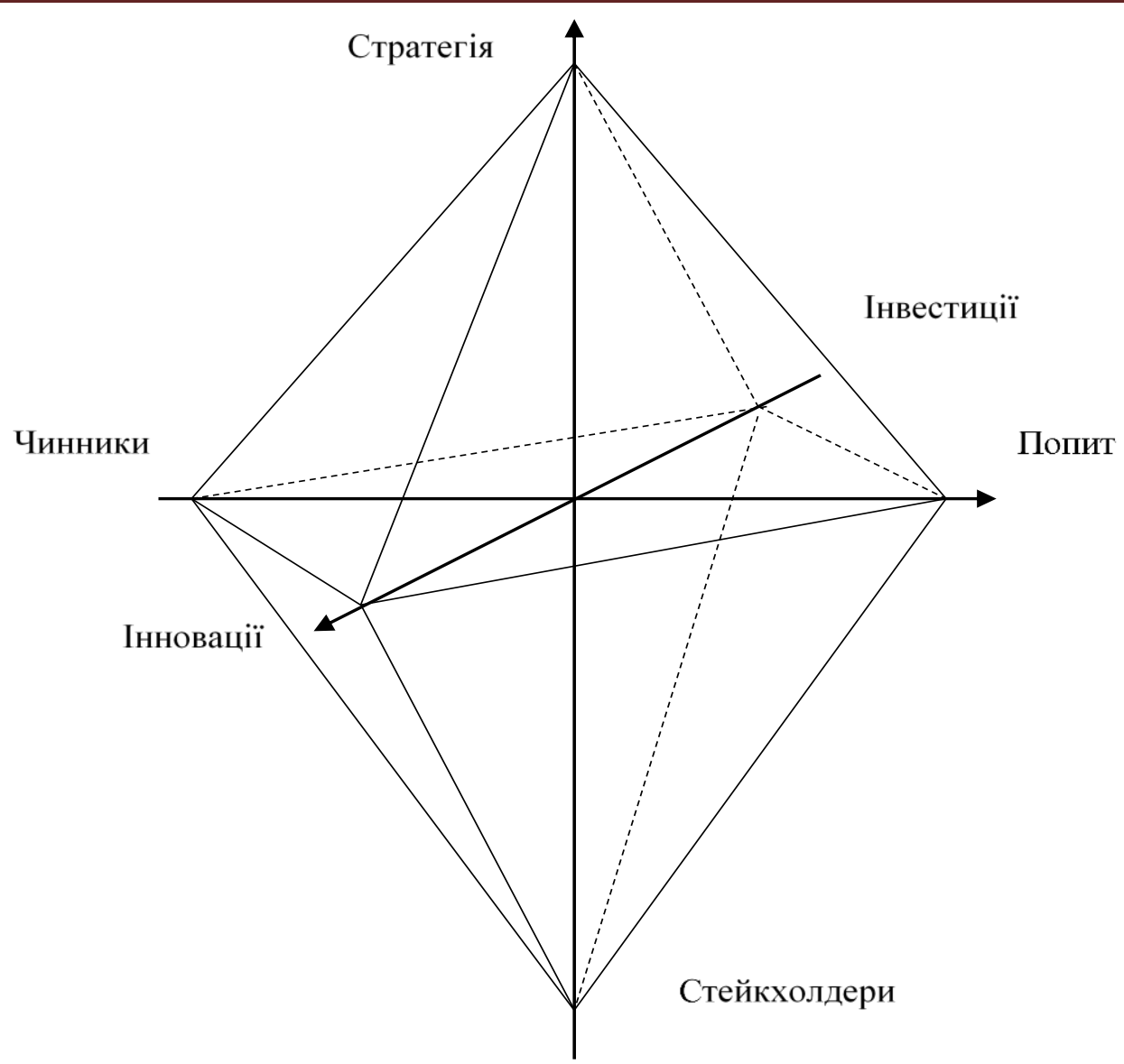

Рис. 6. Чинники формування національної стратегії конкурентних переваг

Джерело: побудовано автором.

Базисом національної агропродовольчої стратегії має стати збалансування параметрів конкурентних переваг 3 обмеженнями щодо сталого природокористування. Однак поки що надходження збору за забруднення навколишнього природного середовища не покривають витрат, спрямованих на його охорону $з$ державного бюджету (рис. 7). Істотні резерви надходжень заховані у відшкодуванні збитку, завданого природі внаслідок нераціонального ведення сільського господарства, яке призводить до деградації грунтів, на відновлення яких скеровується недостатньо коштів, оскільки фінансова відповідальність перекладається на землевласників, тоді як фактичними землекористувачами здебільшого є орендарі, які не заінтересовані витрачати власні кошти на відновлення природної родючості орендованих земель. Значно більшої шкоди довкіллю завдає промислове тваринництво, а надто свинарство та птахівництво, яке в Україні розвивається стрімкішими темпами порівняно зі скотарством - перевага полягає в швидшому обороті продуктивного стада. Свинокомплекси та птахоферми $\epsilon$ потужним джерелом забруднення атмосферного повітря, води та грунту відходами життєдіяльності тварин, утилізація яких є проблемою, що потребує негайного вирішення одночасно із захороненням біологічних відходів від падежу та забою тварин. Наслідком нехтування підприємствами харчової промисловості санітарними нормами та правилами є надмірне забруднення стічних вод. 


\section{Agricultural and Resource Economics: International Scientific E-Journal}

http://are-journal.com

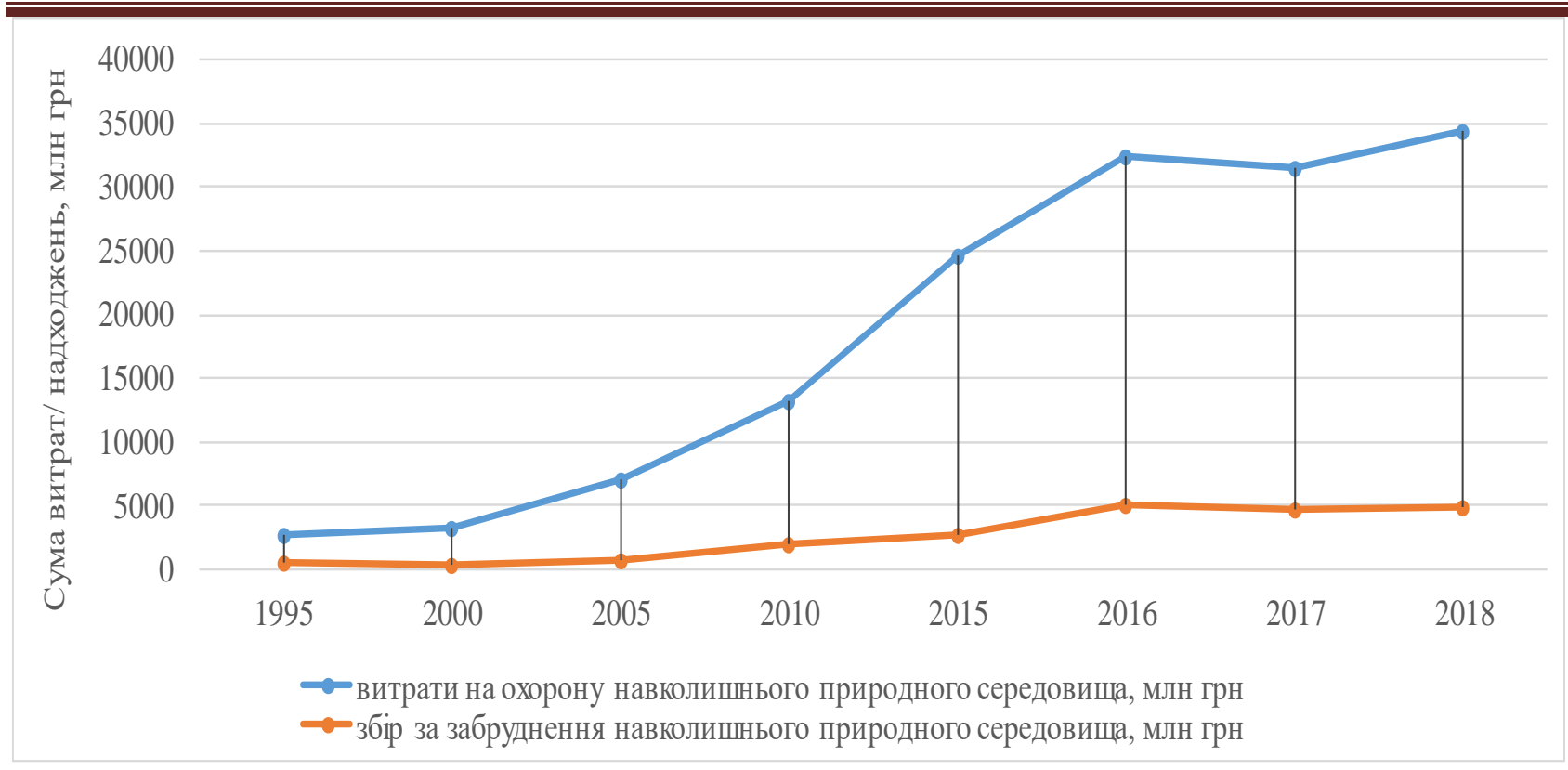

\section{Рис. 7. Різниця надходжень і видатків 3 державного бюджету} на здійснення природоохоронних заходів

Джерело: побудовано автором за даними статистичного збірника «Довкілля України» за відповідні роки.

Причиною стрімкого накопичення в Україні харчових відходів є надмірні обсяги продовольства, що «очікують» свого споживача в закладах торгівлі та готельно-ресторанного господарства. Пошук шляхів зменшення харчових відходів та напрацювання політики їхньої переробки у світі набуває актуальності [30; 31]. Перебуваючи на стадії дослідження, проблема відсутності ефективних заходів, спрямованих на запобігання утворенню, перероблення та утилізацію побічної аграрної продукції та харчових відходів, одночасно 3 низьким рівнем культури населення України щодо поводження 3 відходами різного походження призводять до загострення іншої екологічної проблеми забруднення підземних i наземних водних горизонтів, оскільки $30 \%$ продовольства стає відходами, а $30 \%$ прісної води - скидами. Тому для українського суспільства гостро постає питання забезпеченості його питною водою, що актуалізує напрацювання дієвого механізму контролю в сільському господарстві за землекористуванням і відповідним його виробничим використанням, що передбачає нарахування та стягнення штрафних санкцій за завдавання шкоди навколишньому природному середовищу, залученому у виробничі процеси.

Зберегти природні ресурси України для майбутніх поколінь і спонукати до ведення господарської діяльності на інноваційній основі можливо за умови дотримання принципу сталого природокористування [32]. Екологічні обмеження слугуватимуть стимулом екологізації виробничих процесів, диверсифікації галузевої структури вітчизняної сфери продовольчого забезпечення та запровадження екоінновацій зі зберігання гною [33], переробки та очищення стічних вод i харчових відходів, що дасть змогу вирішити одночасно екологічні, економічні та соціальні проблеми сучасного українського 


\section{Agricultural and Resource Economics: International Scientific E-Journal}

http://are-journal.com

суспільства без загрози для майбутніх поколінь.

Висновки. Проведене аналітичне дослідження дає підстави для загального висновку про хаотичність формування господарських міжгалузевих зв'язків, притаманну сфері продовольчого забезпечення України, що призводить до дисбалансу взаємодії виробничих, збутових i соціальних систем, що виявляються у формі диспропорцій. Основними причинами повільних темпів набуття конкурентних переваг іï секторами є: у сільському господарстві відсутність ринку земель сільськогосподарського призначення; у харчовій промисловості - недостатність сировинної бази через експортну орієнтацію аграріїв; у готельно-ресторанному господарстві - уповільнення туристичних потоків і традиційність українських споживачів щодо домашнього харчування та формування продовольчих запасів, що визначає їхній попит на продукцію сільського господарства.

Урахування впливу відмінностей у традиційних цінностях кожного із поколінь корінного населення України на їхню економічну поведінку визначає актуальність застосування зазначеного підходу продуцентами сфери продовольчого забезпечення до аналізування ринку продуктів харчування та використання його як маркетингового складника в комбінуванні стратегічних граней конкурентних переваг, що дасть змогу уникнути інертності у виробництві продовольчих товарів та ефективніше управляти збутовими ризиками суб'єктам торгівлі.

Домінування молодого покоління в найближчій перспективі, з огляду на його прихильність до мобільності та споживання готової їжі, вимагає напрацювання підходів до попередження ризиків поводження 3 харчовими відходами й тарою, зручною як у цілях доставки до споживача, так i iї утилізації, через запровадження нових тенденцій у споживанні продовольчих товарів та підвищення культури поводження з відходами, що приведе до змін у структурі їхнього продукування та знайде своє відображення у стані довкілля.

В основу формулювання національної стратегії набуття конкурентних переваг має бути покладено реалістичне сприйняття соціально-економічної дійсності, що визначає вектор інновацій, необхідних для відновлення рівноваги між виробництвом і споживанням продуктів харчування, залежно від чинників, що формують потенціал споживчого попиту та екологічних обмежень, орієнтованих на вирішення проблеми задоволення потреб нинішніх поколінь без загрози для майбутніх.

Отож, конкуруючи в сучасних динамічних умовах, недостатньо опиратися лише на природно-ресурсний потенціал і територіальне розміщення, натомість, напрацьовуючи ринкову стратегію, слід зрівноважувати виробничі, технологічні, організаційні, маркетингові та екологічні ії компоненти, що дасть змогу продуцентам сфери продовольчого забезпечення України набути конкурентних переваг, спроможних мінімізувати ризики та максимізувати ефекти від ринкової взаємодії.

Проведене аналітичне дослідження відкриває перспективи для дальшого 
вивчення динамічних залежностей між зміною логіки соціально-економічної поведінки населення та розвитку складників багаторівневої секторальної структури сфери продовольчого забезпечення України на інноваційній основі через виявлення чинників та сили їхнього впливу на споживчу поведінку, ядром якої $\epsilon$ співвідношення матеріальних i моральних цінностей, що формуються під впливом якості й рівня життя, а тому визначають набір економічних потреб i характеристики економічних благ, що мають їх задовольнити.

\section{Список використаних джерел}

1. Сендел М. Что нельзя купить за деньги? Моральные ограничения свободного рынка. Москва: Манн, Иванов и Фербер, 2013. 256 с.

2. Вантух В.П. Методика дослідження ресурсного потенціалу в АПК. Економіка АПК. 2006. № 4. С. 54-58.

3. Голікова К. П. Продовольча безпека держави: сутність, структура та особливості іiі забезпечення. Наукові праці Кіровоградського національного технічного університету. 2012. Вип. 22. Ч. II. С. 1-5.

4. Дейнеко Л. В. Розвиток харчової промисловості України в умовах ринкових перетворень: проблеми теорії і практики. Київ: Знання, 1999. 331 с.

5. Замикула I. В. Механізм державного регулювання системи продовольчого забезпечення у соціально-економічному розвитку регіону. Науковий вісник академї муніципального управління. 2012. Вип. 2. С. 216-224.

6. Пасхавер Б. Й. Сучасний стан продовольчої безпеки. Економіка АПК. 2014. № 4. С. 5-12.

7. Шубравська О. В. Агропродовольчий комплекс України в макроекономічному вимірі. Актуальні проблеми економіки. 2012. № 11(137). С. 113-119.

8. Даниленко М. С. Роль земельних ресурсів у розвитку продовольчого ринку в Україні. Економіка АПК. 2004. № 3. С. 15-19.

9. Вдовенко Н. М., Шарило Ю. С., Курмаєв П. Ю., Дмитришин Р. А. Забезпечення конкурентних переваг рибного господарства 3 використанням прогресивної виробничо-технологічної бази. Проблеми інноваційноінвестиційного розвитку. 2018. № 16. С. 99-108.

10. Патика Н. Пріоритети забезпечення конкурентоспроможності сільського господарства України на світових ринках. Agricultural and Resource Economics. 2018. Vol. 4. No. 4. Рp. 130-145.

11. Бабич М. М. Соціально-економічна та екологічна стійкість коротких ланцюгів постачання: можливості для розвитку сільських територій. Agricultural and Resource Economic. 2018. Vol. 4. No. 1. Pp. 42-59.

12. Синельников В. М., Гануш Г. И. Конкурентные преимущества АПК Беларуси на рынках продовольствия: оценка и факторы формирования. Формирование организационно-экономических условий эфффективного функиионирования АПК: сборн. научн. статей 9-й Междунар. науч.-практ. конф. (г. Минск, 25-26.05.2017 г.). Минск, 2017. С. 42-50.

13. Porter M. E., Kramer M. R. Creating Shared Value. Harvard Business 
Review, 2011. URL: https://hbr.org/2011/01/the-big-idea-creating-shared-value.

14. Koniordos M., Matvienko-Bilyaeva G., Strapchuk S. Strategic scenario of an open source of sustainable development for the food system. Economic Annals-XXI. 2017. No. 165(5-6). Pp. 56-59. https://doi.org/10.21003/ea.V165-12.

15. Mitiai O., Lagodiienko V., Safonov V. Competitiveness of agriculture enterprises as the main factor of sustainable development in agricultural sphere. Economic Annals-XXI. 2015. No. 155(11-12). Pp. 59-62.

16. Kravcakova-Vozarova I., Kotulic R., Sira E. V4 countries' agricultural sector evaluation in terms of competitive advantage. Economic Annals-XXI. 2015. No. 5-6. Pp. 60-63.

17. Земельна реформа. AgroPolit. $2019 . \quad$ URL: https://agropolit.com/news/16491-zbitki-ukrayini-vid-20-richnih-vtrat-gumusu-vgrunti-dosyag-450-mlrd-grn.

18. Волосов А. Інновації як джерело формування конкурентних переваг підприємств торгівлі. Agricultural and Resource Economics. 2016. Vol. 2. No. 4. Pp. 52-63.

19. Органік в Україні. Федерація органічного руху в Україні, 2010-2018. URL: http://organic.com.ua/uk/homepage/2010-01-26-13-42-2915.

20. Yurynets Z., Bayda B., Petruch O. Country's economic competitiveness increasing within innovation component. Economic Annals-XXI. 2015. No.9-10. Pp. 32-35.

21. Мельник К., Пташник С. Теоретичні засади конкурентоспроможності та iі роль у розвитку підприємницької діяльності. Agricultural and Resource Economics. 2018. Vol. 4. No. 2. Pp. 97-114.

22. Toth J., Ferto I. Innovation in the Hungarian food economy. Agricultural Economic - Czech. 2017. Vol. 63. Pp. 43-51. https://doi.org/10.17221/196/2015AGRICECON.

23. Firlej K., Kowalska A., Piwowar A. Competitiveness and innovation of the Polish food industry. Agricultural Economic - Czech. 2017. Vol. 63. Pp. 502-509. https://doi.org/10.17221/111/2016-AGRICECON.

24. Harris L., Ogbonna E. Competitive advantage in the UK food retailing sector: past, present and future. Journal of Retailing and Consumer Services. 2001. Vol. 8. No. 3. Pp. 157-173. https://doi.org/10.1016/S0969-6989(00)00009-6.

25. Стиглиц Дж., Сен А., Фитусси Ж.-П. Неверно оценивая нашу жизнь или Почему ВВП не имеет смысла? Москва: Изд-во Института Гайдара, 2016. 216 с.

26. Just D. R., Byrne A. T. Evidence-based policy and food consumer behavior: how empirical challenges shape the evidence. European Review of Agricultural Economics. 2020. Vol. 47. No. 1. Pp. 348-370. https://doi.org/10.1093/erae/jbz010.

27. Howe N., Strauss W. Generations: the history of America's future, 1584 to 2069. New York: William Morrow and Co, 1991. 538 p.

28. Мудрак Р. П. Поведінка споживача як чинник продовольчої безпеки домогосподарства. Економічний часопис -XXI. 2014. № 3-4(1). С. 27-30.

29. Корецький В. Л., Орлова Н. М. До проблеми безпеки харчування та 
моніторингу якості життя населення України. Проблеми харчування. 2006. № 1. C. $42-44$.

30. Danyi Qi., Brian E. Roe Foodservice composting crowds out consumer food waste reduction behavior in a dining experiment. American Journal of Agricultural $\begin{array}{llll}\text { Economics. } & 2017 . & \text { Vol. 99. } & \text { No. 5. }\end{array}$ https://doi.org/10.1093/ajae/aax050.

31. Katare B., Serebrennikov D., H. Holly Wang, Wetzstein M. Social-optimal household food waste: taxes and government incentives. American Journal of Agricultural Economics. 2017. Vol.99. No. 2. Pp. 499-509. https://doi.org/10.1093/ajae/aaw114.

32. Самофатова В. Принципи стратегічного управління сталим розвитком агропродовольчої сфери регіону. Agricultural and Resource Economics. 2017. Vol. 3. No. 1. Pp. 173-181. https://doi.org/10.22004/ag.econ.256889.

33. Bahorka M. Formation of the ecological-economical management of ecologization of agrarian production. Agricultural and Resource Economics. 2019. Vol. 5. No. 1. Pp. 5-18. https://doi.org/10.22004/ag.econ.287138.

\section{References}

1. Sandel, M. (2013), Chto nelzia kupit za diengi? Moralnyie ogranicheniia svobodnogo rynka [What money can't buy? The moral limits of markets], Mann, Ivanov i Ferber, Moscow, Russia.

2. Vantukh, V. P. (2006), The methods of the investigation of resource potential in AIC. Ekonomika APK, no. 4, pp. 54-58.

3. Holikova, K. P. (2012), The state food security: essence, structure and features of its provision. Naukovi pratsi Kirovogradskogo Natsionalnogo tekhnichnogo universytetu, vol. 22, part II, pp. 1-5.

4. Deineko, L. V. (1999), Rozvytok kharchovoi promyslovosti Ukrainy v umovakh rynkovykh peretvoren: problemy teorii $i$ praktyky [The Ukrainian food industry development in the market transformation conditions: theory and practice problem], Znannia, Kyiv, Ukraine.

5. Zamykula, I. V. (2012), The Government regulation mechanism of food provision in a social-economy development of the region. Naukovyi visnyk akademii munitsypalnogo upravlinnia, vol. 2, pp. 216-224.

6. Paskhaver, B. Y. (2014), The modern stage of food security. Ekonomika APK, vol. 4, pp. 5-12.

7. Shubravska, O. V. (2012), Ukrainian agro industrial complex in the macroeconomic dimension. Aktualni problemy ekonomiky, no. 11(137), pp. 113-119.

8. Danylenko, M. S. (2004), The role of the land resources into food market development in Ukraine. Ekonomika APK, no. 3, pp. 15-19.

9. Vdovenko, N. M., Sharylo, Yu. Ye., Kurmaiev, P. Yu. and Dmytryshyn, R. A. (2018), Ensuring the competitive advantages of fisheries using a progressive production and technological base. Problemy innovatsiino-investytsiinogo rozvytku, no. 16 , pp. $99-108$. 
10. Patyka, N. (2018), Priorities ensuring of the Ukraine's agriculture competitiveness in the world markets. Agricultural and Resource Economics, vol. 4, no. 4, pp. 130-145.

11. Babych, M. (2018), Social-economic and environmental sustainability of short supply chains: opportunities for development rural territories. Agricultural and Resource Economics, vol. 4, no. 1, pp. 42-59.

12. Sinielnikov, V. M. and Ganush, G. I. (2017), Formirovaniie organizatsionno-ekonomichieskich uslovii effektivnogo funktsionirovaniia APK [Creation of an organizational-economic conditions of the AIC' effective work], Miezhdunarodnaia nauchno-praktichieskaia konfierientsiia [International scientificpractical conference], Minsk, Belarus, 25-26 May, pp. 42-50.

13. Porter, M. E. and Kramer, M. R. (2011), Creating Shared Value. Harvard Business Review, available at: https://hbr.org/2011/01/the-big-idea-creating-sharedvalue.

14. Koniordos, M., Matvienko-Bilyaeva, G. and Strapchuk, S. (2017), Strategic scenario of an open source of sustainable development for the food system. Economic Annals-XXI, no. 165(5-6), pp. 56-59. https://doi.org/10.21003/ea.V165-12.

15. Mitiai, O., Lagodiienko, V. and Safonov, V. (2015), Competitiveness of agriculture enterprises as the main factor of sustainable development in agricultural sphere. Economic Annals-XXI, no. 155(11-12), pp. 59-62.

16. Kravcakova-Vozarova, I., Kotulic, R. and Sira, E. (2015), V4 countries' agricultural sector evaluation in terms of competitive advantage. Economic Annals$X X I$, no. 5-6, pp. 60-63.

17. AgroPolit (2019), Lands' Reform, available at: https://agropolit.com/news/16491-zbitki-ukrayini-vid-20-richnih-vtrat-gumusu-vgrunti-dosyag-450-mlrd-grn.

18. Volosov, A. (2016), Innovation as a source of competitive advantages formation for retailers. Agricultural and Resource Economics, vol. 2, no. 4, pp. 52-63.

19. Federation of the organic movement in Ukraine (2010-2018), Organic in Ukraine, available at: http://organic.com.ua/uk/homepage/2010-01-26-13-42-2915.

20. Yurynets, Z., Bayda, B. and Petruch, O. (2015), Country's economic competitiveness increasing within innovation component. Economic Annals-XXI, no. 9-10, pp. 32-35.

21. Melnyk, K. and Ptashnyk, S. (2018), Theoretical basis of competitiveness and its role in development of entrepreneurial activity. Agricultural and Resource Economics, vol. 4, no. 2, pp. 97-114.

22. Toth, J. and Ferto, I. (2017), Innovation in the Hungarian food economy. Agricultural Economic - Czech, vol. 63, pp. 43-51. https://doi.org/10.17221/196/2015-AGRICECON.

23. Firlej, K., Kowalska, A. and Piwowar, A. (2017), Competitiveness and innovation of the Polish food industry. Agricultural Economic - Czech, vol. 63, pp. 502-509. https://doi.org/10.17221/111/2016-AGRICECON.

24. Harris, L. and Ogbonna, E. (2001), Competitive advantage in the UK food 
retailing sector: past, present and future. Journal of Retailing and Consumer Services, vol. 8, no. 3, pp. 157-173. https://doi.org/10.1016/S0969-6989(00)00009-6.

25. Stiglitz, J. E., Sen, A. and Fitoussi, J.-P. (2016), Nievierno otsenivaia nashu zhizn ili Pochiemu VVP nie imieiet smysla? [Mis-measuring our life. Why the GTP doesn't add up?], Gaidar Institute, Moscow, Russia.

26. Just, D. R. and Byrne, A. T. (2020), Evidence-based policy and food consumer behaviour: how empirical challenges shape the evidence. European Review of Agricultural Economics, vol.47, no. 1, pp. 348-370. https://doi.org/10.1093/erae/jbz010.

27. Howe, N. and Strauss, W. (1991), Generations: The history of America's future, 1584 to 2069, William Morrow and Co, New York, USA.

28. Mudrak, R. P. (2014) The consumer behavior as a factor of the households' food security. The Economic Annals - XXI, no. 3-4(1), pp. 27-30.

29. Koretskii, V. L. and Orlova, N. M. (2006), To the problem nutrition safety and monitoring of the life quality of Ukraines' population. Problemy kharchuvannia, no. 1 , pp. $42-44$.

30. Danyi, Qi. and Brian E. Roe (2017), Foodservice composting crowds out consumer food waste reduction behavior in a dining experiment. American Journal of Agricultural Economics, vol. 99, no. 5, pp. 1159-1171. https://doi.org/10.1093/ajae/aax050.

31. Katare, B., Serebrennikov, D. Holly Wang, H. and Wetzstein, M. (2017), Social-optimal household food waste: taxes and government incentives. American Journal of Agricultural Economics, vol.99, no. 2, pp.499-509. https://doi.org/10.1093/ajae/aaw114.

32. Samofatova, V. (2017), Principles of strategic management of sustainable development of agri-food sphere of the region. Agricultural and Resource Economics, vol. 3, no. 1, pp. 173-181. https://doi.org/10.22004/ag.econ.256889.

33. Bahorka, M. (2019), Formation of the ecological-economical management of ecologization of agrarian production. Agricultural and Resource Economics, vol. 5, no. 1, pp. 5-18. https://doi.org/10.22004/ag.econ.287138.

\section{Citation:}

\section{Стиль-ДСТУ:}

Глубіш Л. Перешкоди формуванню конкурентних переваг у секторах сфери продовольчого забезпечення України. Agricultural and Resource Economics. 2021. Vol. 7. No. 1. Pp. 115-136. https://doi.org/10.51599/are.2021.07.01.07.

Style-APA:

Glubish, L. (2021), Barriers to creating of competitive advantages in the sectors of food provision sphere of Ukraine. Agricultural and Resource Economics, vol. 7, no. 1, pp. 115-136. https://doi.org/10.51599/are.2021.07.01.07. 